\title{
Organotemplate structures in sedimentary manganese carbonates of the Neoproterozoic Penganga Group, Adilabad, India
}

\author{
Joydip Mukhopadhyay*, Jens Gutzmer and Nicolas J Beukes \\ Rand Afrikaans University, Department of Geology, PO Box 524, Auckland Park, \\ Johannesburg 2006, South Africa. \\ *Present address: Department of Geology, Presidency College, 86/1 College Street, Kolkata 73, India. \\ e-mail: joydip17@rediffmail.com
}

\begin{abstract}
Manganese carbonates interstratified with bedded chert in the Chanda Limestone of the Neoproterozoic Penganga Group at Adilabad, south India, have been studied for possible evidence that microbiota played a role in the mediation of early diagenetic Mn-carbonate formation in Precambrian marine sedimentary successions. The manganese carbonate and chert beds occur within a below wave base, deep-water distally steepened ramp succession. High resolution SEM petrography of the manganese carbonates revealed two basic morphologies - spherical to oval-cylindrical shaped microconcretions, and tubular to irregular, elongated, film-like microstructures. Infolded filmy to hollow tubular strand-like internal morphologies of the spherical to oval-cylindrical shaped microconcretions suggest their microbial affinity. The tubular and film morphologies with meshlike interconnections closely resemble architectures of microbial extracellular polymeric substance (EPS). Mineralization took place on these organotemplates by the process of permineralization as well as replacement in an early diagenetic pore-water environment with reduction of higher manganese oxy-hydroxides by organic matter and consequent increase in dissolved carbonate.
\end{abstract}

\section{Introduction}

In modern marine environments, manganese is precipitated as $\mathrm{Mn}(\mathrm{IV})$ oxyhydroxides from oxygenated surface water (Johnson et al 1996). However, manganese-rich sediments accumulate only where oxygenated surface water mixes with oxygen deficient water that is able to introduce significant concentrations of dissolved $\mathrm{Mn}$ (II) into the depositional environment (Frakes and Bolton 1992). Mixing of these two water masses results in the oxidation of $\mathrm{Mn}(\mathrm{II})$ to poorly soluble $\mathrm{Mn}(\mathrm{IV})$ oxyhydroxides. Once formed, these oxyhydroxides precipitates only escape redissolution if they accumulate in an aerobic sedimentary environment, i.e., if the water above the sedimentwater interface remains too oxygenated to permit immediate reduction and dissolution of the Mn(IV) oxyhydroxides.

Given these preconditions, shallow marine environments surrounding epicontinental basins with deep, oxygen-deficient water masses overlain by a highly oxygenated shallow water column are most suited for the efficient accumulation of manganeserich sediments. Manganese precipitates accumulate where deeper anoxic water interfaces with oxygenated shallow marine water on the shelf. The same depositional environment is marked by high biogenic activity, as the upwelling deep water is rich in nutrients required by photosynthetic organisms that flourish in the photic zone. As a result, $\mathrm{Mn}(\mathrm{IV})$ oxyhydroxides are usually deposited together with organic matter. Under suboxic early diagenetic conditions the 

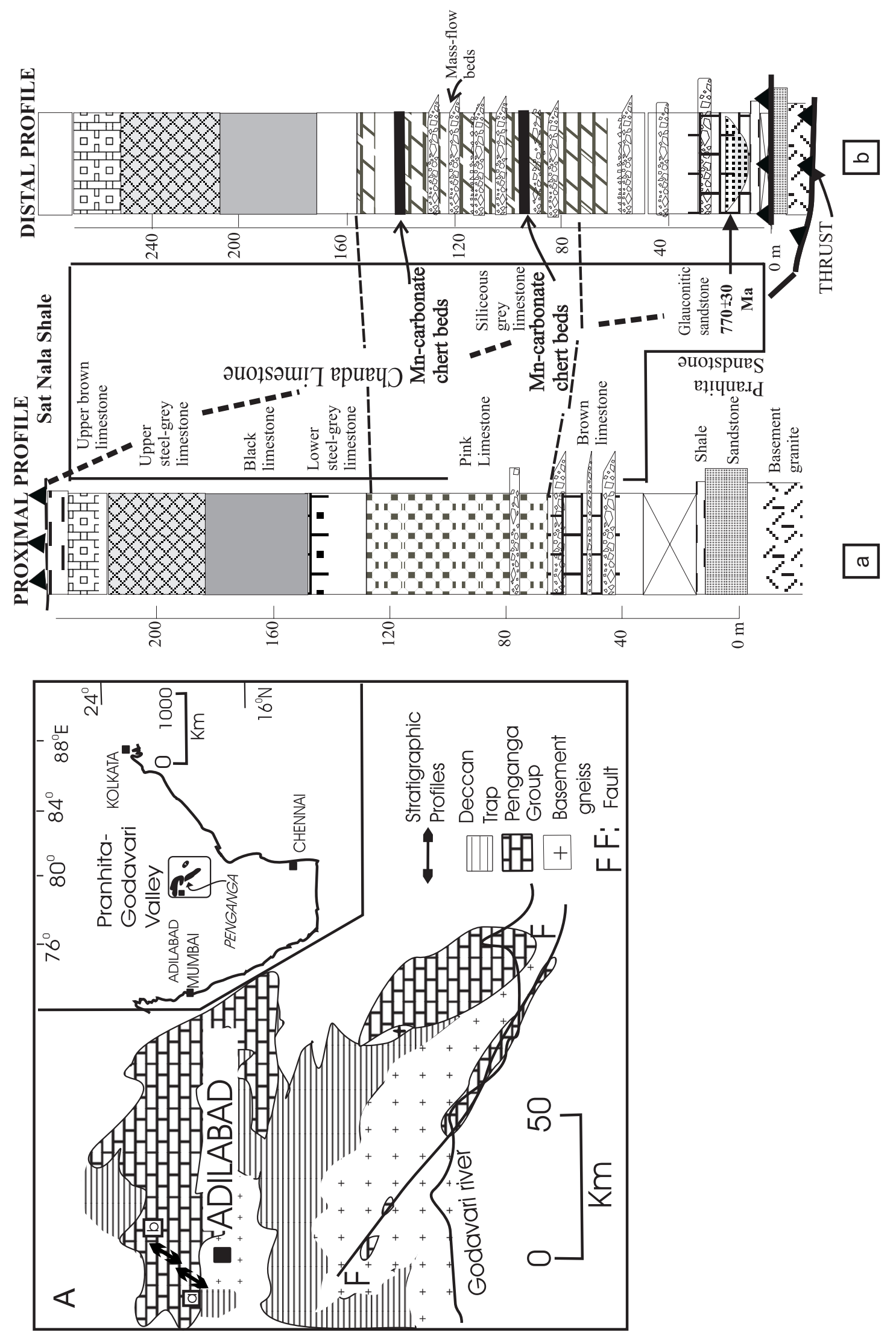

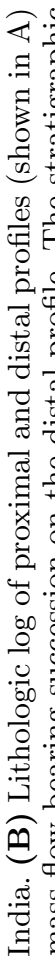


Mn-oxyhydroxides are then reduced by heterotrophic bacteria at the expense of organic matter, to form Mn-rich carbonates, such as rhodochrosite and kutnahorite. Convincing evidence for this early diagenetic redox reaction is provided by the unusually light $\delta^{13} \mathrm{C}$ values that are characteristic for Mn-carbonates in sedimentary rocks, which can be explained only by a contribution of isotopically light carbonate carbon derived from the diagenetic oxidation of organic matter (Okita et al 1988). Sedimentary rocks rich in these early diagenetic Mn-carbonates are then the precursor of most, if not all, economic sedimentary manganese oxide deposits, formed by supergene enrichment in present-day and ancient weathering profiles (Dammer et al 1996; Morad and Al-Asam 1997; Öztürk and Hein 1997; Roy 1997; Fan and Yang 1999; Fan et al 1999; Hein et al 1999).

Not only are microbial organisms likely to be the most important suppliers of the organic carbon required for the formation of early diagenetic manganese carbonates, but their more direct involvement in the reduction of manganese oxyhydroxide precipitates at or below the sedimentwater interface has often been proposed for modern and ancient environments (Hein and Koski 1987; Okita et al 1988; Polgãri et al 1991; Okita 1992; Huckriede and Meischner 1996; Neumann et al 2002). It is surprising that only few studies provide direct, textural evidence illustrating this suspected involvement of microbial organisms in the formation of diagenetic manganese carbonates (e.g., Fan et al 1999; Hein et al 1999).

Pristinely preserved and unmetamorphosed manganese carbonate beds of the Penganga Group (770 $\pm 30 \mathrm{Ma}$; Chaudhuri et al 1989) around Adilabad in the Pranhita-Godavari Valley, south India (figure 1A), provide an excellent opportunity for detailed petrographic studies of early diagenetic manganese carbonates of Neoproterozoic age. Gutzmer and Beukes (1998) first reported on these manganese carbonates and provided detailed major, trace, REE and $\mathrm{C}$ and $\mathrm{O}$ isotope geochemical data. They considered microbially mediated suboxic diagenesis with reduction of $\mathrm{Mn}^{+4}$ oxyhydroxides by organic carbon as instrumental to the origin of these carbonates. In this paper, we report the discovery of abundant microconcretionary structures that resemble EPS (extracellular polymeric substance)-like organotemplate morphologies in the Mn-carbonate ores and discuss the probable role of microbial activity on their origin.

\section{Methodology}

Samples of Mn-carbonates were collected from operating and abandoned open mine pits. Great care was taken during sampling to avoid weathered or otherwise altered samples. Polished chips and cuts oriented across, as well as parallel to bedding, were used for petrographic studies. Chips were first cleaned in ultrasonic bath for 15 minutes and rinsed with acetone and dried. A number of samples were etched with dilute (20\%) acetic acid for 2-3 hours and rinsed with distilled water. Samples were not soaked nor wrapped with tissue paper to avoid any contamination or formation of artifacts. Finally, the dried samples were gold-coated for 30 seconds and studied using both secondary electron imaging as well as backscattered energy dispersive X-ray analysis on a JEOL 5600 scanning electron microscope (SEM) in the Centralized Analytical Facility of the Rand Afrikaans University.

\section{Geologic setting}

The Penganga Group (figure 1B) comprises, from bottom to top, the Pranhita Sandstone $(25 \mathrm{~m})$, the Chanda Limestone $(300 \mathrm{~m})$ and the Sat Nala Shale $(>2000 \mathrm{~m})$ (Chaudhuri et al 1989; Chaudhuri and Chanda 1991; Mukhopadhyay 1997). The Chanda Limestone, which hosts the manganese carbonate beds, is dominated by micritic limestone with laterally persistent medium- to thickbedding (Chaudhuri et al 1989; Mukhopadhyay et al 1996). Limestone mass flow deposits, a glauconitic sandstone of mass flow origin, and interstratified bedded chert-manganese carbonate ore bodies constitute subordinate components of this formation (figure 1B). Based on stratigraphic and facies analyses, Mukhopadhyay (1997) suggested a deep-water, distally steepened ramp to homoclinal ramp-platformal depositional setting below wave base for the Chanda Limestone. The bedded chert-manganese ore beds are restricted to the distally steepened ramp slope and base-of-slope (Mukhopadhyay et al 1997). The available radiometric age data on the Penganga Group come from the $\mathrm{Rb}-\mathrm{Sr}$ date of $770 \pm 30 \mathrm{Ma}$ and $790 \pm 30 \mathrm{Ma}$ from glauconites in the lower part of the succession (figure 1B) (Chaudhuri et al 1989).

Two laterally persistent manganese carbonate beds are interstratified with bedded chert (Mukhopadhyay et al 1999) (figures 1B, 2A) within the siliceous grey limestone interval in the central part of the Chanda Limestone. The manganese carbonate beds are pink to brownish red in colour. Variable amounts of hematite and kerogen often impart reddish to rusty brown colour. They are microlaminated (figure 2B) with millimetre-thick, laterally persistent, plane, wavy to crinkly laminations (figure 2B) and are composed of kutnahorite and rhodochrosite with minor amount of 


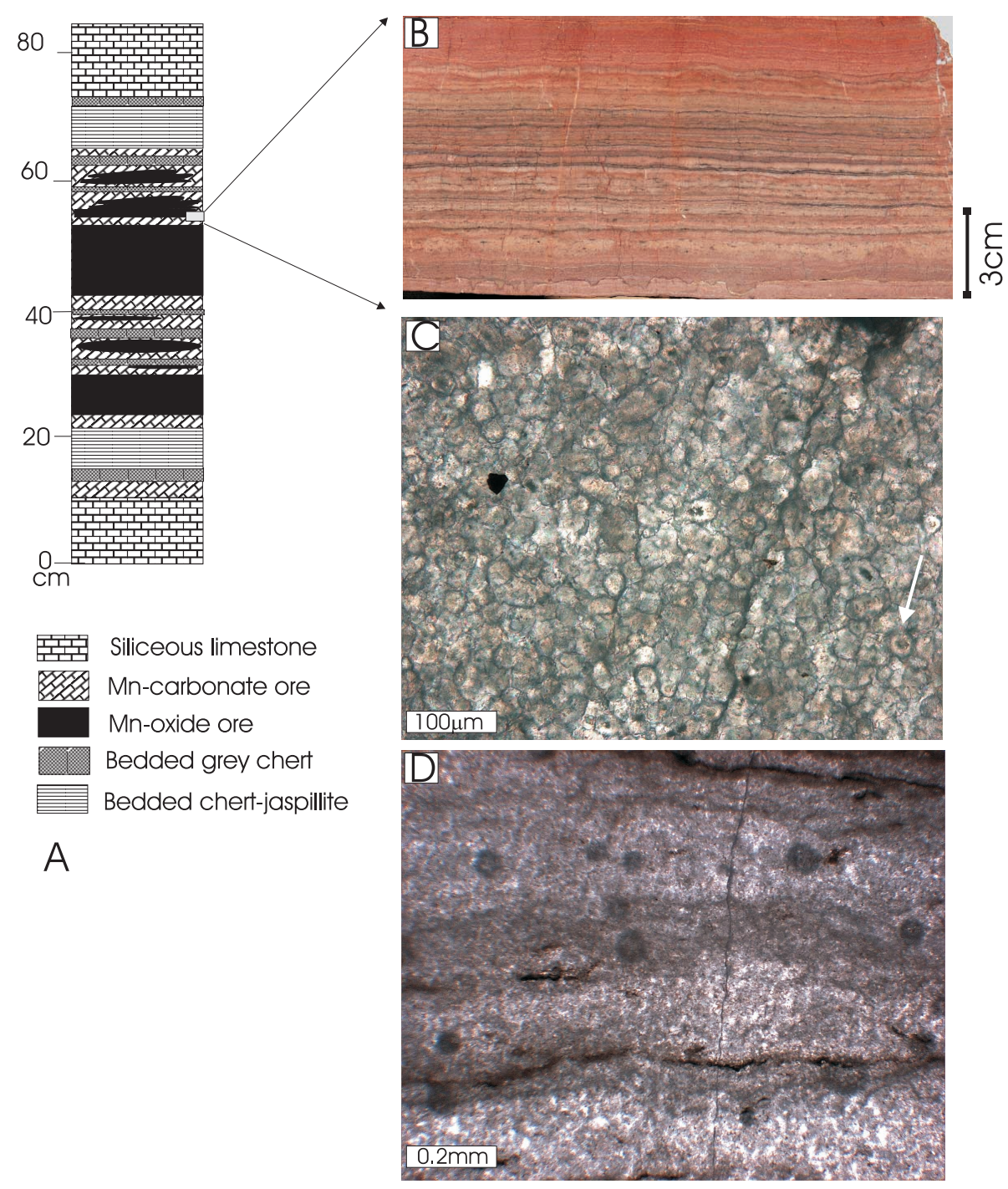

Figure 2. (A) Lithologic log of interstratified bedded chert and manganese ore interval. (B) Hand-specimen photograph of laminated Mn-carbonate rock. Note thin wrinkle laminae near the middle. (C) Photomicrograph of rhodochrositekutnahorite microconcretions. Note circular to subcircular outline of the microconcretions, dark inclusions of iron oxides and carbonaceous matter (arrow) in many of them. Scale bar $100 \mu \mathrm{m}$. (D) Laminated microconcretions. Note concentration of dark carbonaceous matter along lamina.

cherty intercalations. The beds are essentially composed of circular to subcircular, $5-100 \mu \mathrm{m}$-sized rhodochrosite or kutnahorite microconcretions (figure 2C) locally cemented by either sparry Mncalcite or by microquartz (Gutzmer and Beukes 1998). Many of these carbonate microconcretions show evidence of having been redeposited. Redeposited beds display normal grading with an erosional basal bounding surface and locally comprise matrix-supported intraformational, pebbly calcarenite with clasts and a matrix of kutnahorite and rhodochrosite microconcretions. The textural characteristics of these beds suggest that the Mncarbonate microconcretions formed at or immediately below the water-sediment interface, no more than a few mm or so from the surface. The presence of graded beds with erosive lower contacts indicates that many of these beds are resedimented in the slope/base-of-slope environments. However, common occurrences of compound aggregates of intergrown microconcretions as well as perfect round outline under thin-section (figure $2 \mathrm{C}$ ) also indicate in situ growth in many beds.

Tiny amounts of carbonaceous matter are locally preserved as dark brown to dirty patches along laminae (figure 2D). The $\delta^{13} \mathrm{C}_{\mathrm{PDB}}$ of the $\mathrm{Mn}$ carbonates varies between $-2.0 \mathrm{~h}$ and $-6.86 \mathrm{~h}$ and $\delta^{18} \mathrm{O}_{\mathrm{PDB}}$ ranges from $-4.33 \mathrm{~h}$ to $-9.56 \mathrm{~h}$ (Gutzmer and Beukes 1998). In contrast, the host siliceous grey limestone yielded heavier $\delta^{13} \mathrm{C}_{\mathrm{PDB}}$ values averaging $+2.0 \mathrm{~h}$ and $\delta^{18} \mathrm{O}_{\mathrm{PDB}}$ averaging -7.0h (Gutzmer and Beukes 1998). Corg content of the Mn-carbonates varies from 0.23 to $0.30 \mathrm{mg} / \mathrm{gm}$ compared to $<0.2 \mathrm{mg} / \mathrm{gm}$ of the host 
siliceous limestone and other limestone intervals except the black limestone that contains about $1 \mathrm{mg} / \mathrm{gm}$ Corg (Gutzmer and Beukes 1998). Intercalated chert beds are finely laminated grey, black or red jaspery in nature.

\section{SEM petrography}

SEM studies on etched as well as unetched samples of Mn-carbonate beds revealed two basic carbonate microstructures:

- spherical to oval-cylinder shaped microconcretions, and

- tubular to irregular, elongated, film-like microstructures.

Spherical to oval-cylindrical shaped (fir-cone of Gutzmer and Beukes 1998) microconcretions are most common microstructures and make up more than $95 \%$ of the $\mathrm{Mn}$-carbonate beds (figure 3A). In etched samples they form an open framework with locally preserved twisted Mn-carbonate films surrounding the microconcretions (figure $3 \mathrm{~B}$ ). These microconcretions are subcircular in cross-section with diametres of 5 to $100 \mu \mathrm{m}$ and lengths between $10 \mu \mathrm{m}$ and $100 \mu \mathrm{m}$. A majority of the capsules are $5-10 \mu \mathrm{m}$ in diametre and 15 to $25 \mu \mathrm{m}$ in length. Commonly, they occur as solitary entities (figure 3C) but locally they form aggregates. Internally, each microconcretion is made up of a number of 2 to $4 \mu \mathrm{m}$ size filmy microstructures with infolded margins and are concentrically arranged in tiers defining a porous framework (figure 3C). Individual film-like microstructures, in close up, show smooth to ropy surface textures with interconnecting fibrillar strands (figure 3D). Carbonate rhombs are embedded within these films (figure 3D, E). Higher magnification reveals locally developed mesentery-like fibrillar strands among tiers of films. Locally, films include circular to subcircular holes with smooth outline (figure 3E). Hollow branching tubular strands are also preserved locally in some concretions (figure 3F).

Tubular to irregular, elongated, film-like microstructures occur dispersed in the framework of spherical to oval-cylindrical shaped microconcretions. In general, these are hollow structures with tubular to irregular and filmy geometry (figure 4A, $\mathrm{B}, \mathrm{C})$. Their surface texture is variable from smooth (figure 4A, C, D) to fibrillar (figure 4B). Higher magnification reveals an intricate anastomosing microporous network in the fibrillar film (figure 4B). On back-scattered EDS image these microstructures are darker (figure 4D) and show significantly higher concentration of carbon (kerogen?) (figure $4 \mathrm{E}$ ) over the surrounding spherical to oval-cylindrical shaped Mn-carbonate microconcretions. Similar darker patches also occur in the intergranular spaces of the spherical to ovalcylindrical shaped microconcretions (figure 4E). Locally, micron-scale spheroidal as well as rhombic Mn-carbonates nucleate on the surfaces of films (figure $4 \mathrm{~F}$ ).

\section{Discussion}

\subsection{Evidence for mineralized microbial forms}

High-resolution SEM petrographic studies have recently yielded a wealth of information regarding the presence of microbiota during the formation and diagenesis of carbonate sediments and rocks (Lowenstam 1981; Krumbein and Swart 1983; Chafetz and Folk 1984; Chafetz and Buczynski 1992; Castanier et al 1999; Folk 1993, 1999; Nealson and Stahl 1997; Folk and Lynch 2001); not necessarily implying that the microbiota played a direct role in carbonate precipitation. In an illustrative review on microbial carbonates, Riding (2000) defined microbes as 'all microscopic organisms, generally considered to encompass bacteria (including cyanobacteria), fungi, small algae and protozoans'. Microbes could be potentially instrumental in precipitation of various forms of carbonates as well as other minerals (Skinner 1993; Westall and Rincé 1994; Folk and Chafetz 2000). Most important evidences in this regard, though 'circumstantial', include size, shape, habit and organisation of minerals that mimic the habits of putative microbial structures and styles of organisation (Buczynski and Chafetz 1991; Folk 1993; Westall 1999).

Extracellular polymeric substance (EPS) that accumulates outside bacterial cells as well as biofilms (submillimetric veneers of bacterial communities) (Westall et al 1995) and their fossilized remains are believed to be proxy evidence for the presence of microbial life forms in ancient rock records (Westall et al 2000), and are of central importance in the formation of microbial carbonates (Riding 2000). Bacterial colonies are always associated with EPS of their own production. Mineral replacement may occur in which the EPS and biofilms act as organotemplate for mineral nucleation, after which it degrades and disappears, leaving a mineral cast and/or crust (cf. Westall 1999).

The habits of Mn-carbonates in the Chanda Limestone described here closely resemble structures and forms of somewhat degraded EPS (cf. Buczynski and Chafetz 1991; Westall and Rincé 1994). Hollow tubular or infolded filmlike structures (figure $3 \mathrm{D}, \mathrm{E}$ ) in the spherical to 

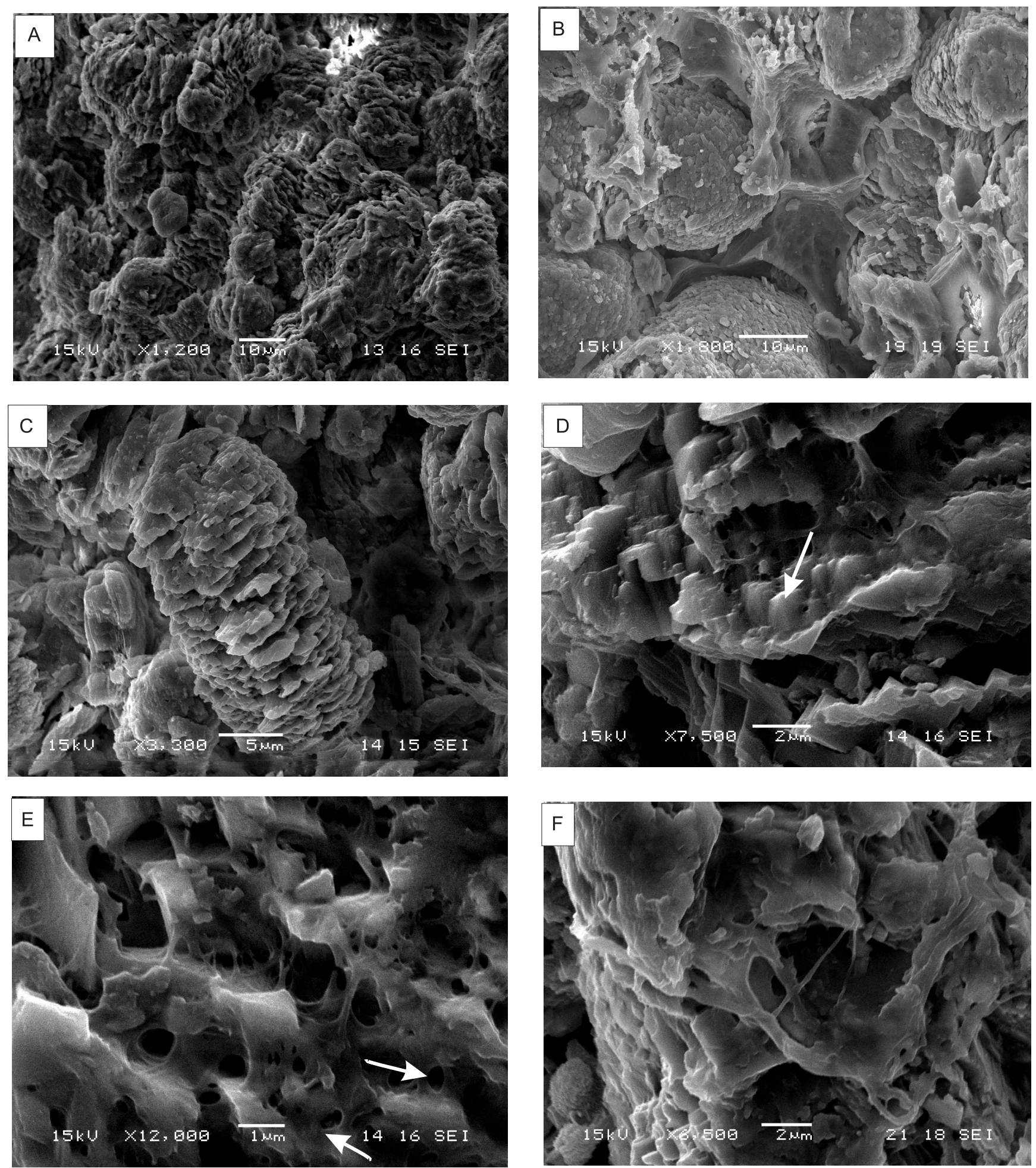

Figure 3. SEM images (SEI) of organotemplate structures in spherical to oval-cylindrical shaped microconcretions (A-F) of Mn-carbonates: (A) Open framework texture of microconcretions, (B) Twisted films of Mn-carbonates squashed between spherical to oval-cylindrical shaped microconcretions, (C) Enlarged view of a spherical to oval-cylindrical shaped microconcretion, note filmy infolded film-like microstructures arranged in tiers, (D) Enlarged portion of C, showing filmy, fibrillar film of carbonates with infolded margins, note vertically arranged fibrillar strands connecting adjacent tiers, also note Mn-carbonate rhombs precipitated on films (arrow), (E) Enlarged view of internal structure in spherical to oval-cylindrical shaped microconcretion showing filmy fibrillar strands of Mn-carbonates, note films with circular to subcircular holes with smooth outline (arrows), (F) Tubular branching microstructures within microconcretions. 

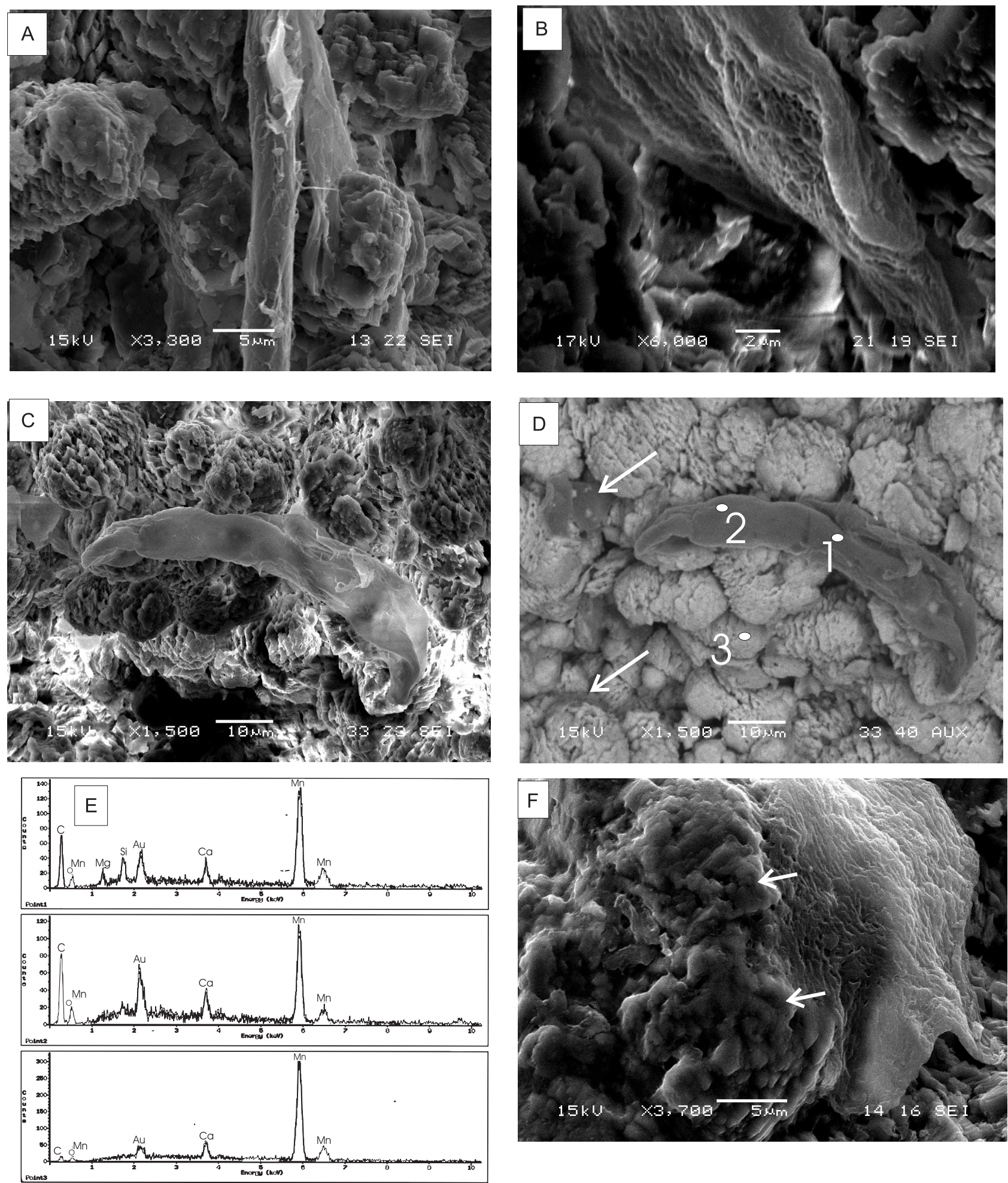

Figure 4. SEM images of tubular to irregular, elongated, film-like organotemplate microstructures of Mn-carbonates: (A) Tubular and somewhat flattened film with spherical to oval-cylindrical shaped microconcretion attached to the film, note filamentous films grading into the microconcretionary plates, (B) A flattened fibrillar film of Mn-carbonate with reticulate surface structure, (C) A hollow smooth infolded film-like Mn-carbonate with ropy fibrillar protrusions, (D) Backscatter image of the same form in $\mathrm{C}$ in which the film-like forms remain darker than the surrounding spherical to oval-cylindrical shaped microconcretions, note similar dark filmy films (arrows) in the intergranular areas of the spherical to oval-cylindrical microconcretions, numbered points correspond to points analysed for composition given in E, (E) Backscatter elemental composition of the dark sheath and spherical to oval-cylindrical shaped microconcretions in D, note significantly higher concentration of carbon in dark sheath (points 1 \& 2) over the surrounding spherical to oval-cylindrical shaped microncretions (point 3), also dominantly $\mathrm{Mn}(\mathrm{Ca}, \mathrm{Mg}$ )-carbonate composition of the microconcretions, (F) Rhombs and spheroids (arrows) of Mn-carbonates growing from a somewhat deflated film-like Mn-carbonate, note reticulate surface of the film. 
oval-cylindrical shaped microconcretions could represent mineralized degraded EPS templates (e.g., Krumbein and Swart 1983; Westall and Rincé 1994; Westall et al 2000). The curved infolded nature and ropy surface texture (figure 3D) is indicative of EPS morphology (Westall et al 2000). The porous meshes of interconnecting tubules and films also mimic the architecture of typical fibrillar biofilms (Westall and Rincé 1994). Rounded to subrounded holes in the filmy material are common components of biofilm polymer (e.g., Westall et al 2001). Locally preserved branching tubular structures within the concretions (figure $3 \mathrm{~F}$ ) may represent either degraded filamentous microbes (e.g., Seong-Joo and Golubic 1998) or simply strands of EPS

Tubular to irregular, elongated, film-like forms of Mn-carbonates offer perhaps the most convincing circumstantial evidence in favour of microbial template-controlled mineralization. The tubular structures may represent strands of EPS or cyanobacterial filaments. Given the extreme degraded state of preservation it is impossible to distinguish between the two unequivocally. The irregular twisted forms attached or unattached to tubes are likely to represent remnants of empty and somewhat deflated and degraded EPS covers of cyanobacteria or fungal hyphae (cf. figure 2.14 in Krumbein and Swart 1983). The reticulate network microstructure preserved in some of the film-like forms (figure 4B) is reminiscent of fibrillar mucus structures of EPS (e.g., Folk and Lynch 2001). Their relative abundance of carbon as reflected in the elemental EDS spectra of somewhat deflated films (e.g., figure 4E) strongly supports relict kerogen in them and their organic precursor. The negative $\delta^{13} \mathrm{C}_{\mathrm{PDB}}$ of the Mn-carbonates (between $-2.0 \mathrm{~h}$ and $-6.86 \mathrm{~h}$ ) in contrast to the low positive (around $+2.0 \mathrm{~h}$ ) values of the host siliceous grey limestone (Gutzmer and Beukes 1998) are suggestive of the incorporation of organic carbon during the formation of these Mn-carbonates.

\subsection{Origin of mineralization}

Lowenstam (1981) suggested two fundamental processes of biogenic mineral formation. The first mechanism is an 'organic matrix-mediated' process in which appropriate ions are actively introduced, induced to crystallize and grow under genetic control in an organic matrix mould. The second process is 'biologically induced' mineralization that promotes extracellular and intracellular mineralization without participation of genetic controls. Many higher organisms with hard exoskeletons adopt the first mechanism whereas the second mechanism operates in primitive life forms like bacteria and algae. The megascopic distinction between the two mechanisms lies in the morphology and organization of the mineral precipitates. The organic matrix-mediated precipitation yields strictly organized genetic blueprint characteristics of particular organisms whereas the biologically induced precipitation resembles inorganic precipitates without any genetic control.

The absence of any elaborate orientation and habit of Mn-carbonates forming the microconcretions in the Penganga deposits preclude the organic matrix-mediated mechanism. However, retention of some kind of forms that primarily resemble EPS or degraded EPS architecture suggests organotemplate-controlled mineralization. The mineralization either could be simply passive inorganic, it could also be biologically induced in which case organic matter serves as an active template for nucleation of carbonates, or it could be the result of a biogenically induced stage followed by an inorganic precipitation stage. We have no means to unequivocally distinguish these possibilities. A template is believed to involve control, in the form of molecular recognition, local supersaturation, and complexing, the formation of molecular superstructures for defining the size and shape of mineral precipitates. EPS in modern cells serves as a molecular blueprint that controls nucleation kinetics and promotes the self-organized growth of minerals (Cölfen and Antonietti 1998). In particular, amphiphilic organic molecules can self-organize into 3D complex aggregated structures and influence the crystallization of inorganic matter (e.g., Sedlak et al 1998). The important point is that the consistency of the internal architecture and organization of the spherical to oval-cylindrical shaped microconcretions described here implies a template-controlled process, and the mineralized forms preserved here represent microbial/organic templates.

Biofilms and EPS surfaces are commonly regarded as surfaces of maximum gradients for ion activities between the bacterial colony and its surroundings as a result of microbial metabolic processes (Westall 1999). It is likely that such surfaces are kinetically the most suitable sites for induction of nucleation and growth of minerals. One of the causes for mineralization controlled by EPS is that constituent polysaccharides possess abundant anionic carboxyl and hydroxyl groups that provides potential binding sites for metals. As a result of cellular metabolism, micro-organisms alter the chemical microenvironment around the cell, modulating the $\mathrm{pH}$, as well as the concentration of a variety of organic and inorganic solutes. This can induce the large-scale precipitation of authigenic minerals in natural environments. Ions may reach concentrations sufficient to promote 
replication of the soft tissues (or the microbial mat itself) by early diagenetic mineralization, especially in anaerobic environments. Such early mineralization is suggested by some as an important factor in promoting organic matter preservation (Allison and Briggs 1991).

Microbial organisms use $\mathrm{Mn}^{+4}$ oxides as electron acceptors to oxidize organic carbon and supply excess $\mathrm{CO}_{2}$ to the ambient pore water facilitating carbonate precipitation. Mn-carbonates are known to be mediated by manganese reducing heterotrophic bacteria like Geobactor and Schewanella (Little et al 1997). Light $\delta^{13} \mathrm{C}$ signatures recorded for rhodochrosite, ankerite, and kutnahorite suggest their diagenetic origin within manganese reduction/iron reduction $(\mathrm{MnR} / \mathrm{FeR}$ ) zones (cf. Coleman 1985; Curtis et al 1986; Okita et al 1988; Curtis 1995) at or close to sediment-water interface.

The spherical to oval-cylindrical shaped morphology of the Mn-carbonate microstructures is beyond satisfactory resolution at our present level of understanding. The tubular to irregular filmy carbonaceous structures (figures 3B, 4E) look like degraded filamentous organisms or simply degraded clumps of polymeric material. The poor preservation of the latter indicates that many of these are probably detrital. The filaments could represent degraded biofilms of cyanobacteria or hyphae of fungi. The microconcretions either represent (a) Mn-carbonate crystals growing in resedimented, degraded carbonaceous matter, or, (b) if there is a cyanobacterial component, the concretions formed in the void space of empty films formed around small colonies of cyanobacteria that have since disappeared and in which case they have been flattened (hence the cylinder-shape and preferred orientation). The mineral precipitate has displaced the original, degraded organic matter such that it is squashed between the concretions. The conspicuous presence of EPS or degraded EPS architecture in the internal structure of the microconcretions favours the second alternative.

Permineralization of organic templates as well as their replacement by minerals are believed to be instrumental to the preservation of microbial signatures in rock record (cf. Westall 1999). Locally preserved carbonaceous matter together with typical EPS morphology indicates the process of permineralization of organic templates for the origin of the Mn-carbonates in the Chanda Limestone. The presence of well-developed rhombs of Mn-carbonates impregnated within film-like Mncarbonates (figures $3 \mathrm{D}, \mathrm{E}$ and $4 \mathrm{~F}$ ) also suggests mineral replacement of the organic structures. The wide variety of microconcretionary structures in the Penganga Mn-carbonates may suggest a combination of mechanisms by which the organic films and structures became coated by Mn-carbonates during early diagenesis through a biogenically induced template-controlled precipitation. This probably continued to an abiotic process of precipitation and growth of early formed crystals.

\section{Conclusion}

Petrographic studies of manganese carbonates in the Penganga Group revealed the presence of spherical to oval-cylindrical shaped and tubularto film-like microconcretionary structures. The nature and morphology of microstructures closely resemble microbial EPS or biofilm-like architecture. Mineralization was likely to be controlled and/or induced by these organotemplates in an early diagenetic environment with reduction of higher manganese oxyhydroxides by organic matter and consequent increase in carbonate concentration. Although it is almost impossible to unequivocally distinguish between strictly biologically induced and abiotic precipitation of $\mathrm{Mn}$ carbonates, the circumstantial evidences on their habits and consistency of internal organisation together with the stable isotope data strongly points to a microbially induced template-controlled permineralization followed by abiotic precipitation and growth of early-formed crystals.

\section{Acknowledgements}

We acknowledge with thanks logistic support provided by Indian Statistical Institute, Kolkata, during fieldwork. We would also like to extend our sincere thanks to Asru Kumar Chaudhuri for many fruitful discussions. JM acknowledges the South African National Research Foundation (NRF) for a post-doctoral bursary to conduct research at RAU in South Africa, and the Govt. West Bengal, India, for sanctioning him study-leave for this purpose. In-depth reviews by David T Wright and Frances Westall have greatly improved the contribution.

JM adds: It is a great opportunity for me to contribute this article in memory of my teacher, philosopher and guide, the Late Prof. Sukomol Kumar Chanda. Prof. Chanda was one of the greatest and rare breeds of teachers of postindependence Indian geology with traditional values and ethics. I profoundly acknowledge his influence and teaching on all forms of my academic research, teaching and personal life. I also acknowledge his wife, Mrs. Bula Chanda, Sejoboudi (wife of his elder brother) and other family members who had to sacrifice invaluable personal moments that we stole from them in our preoccupations with Prof. Chanda during odd hours of those days. 


\section{References}

Allison P A and Briggs D E G 1991 Taphonomy of nonmineralized tissues; In: Taphonomy; releasing the Data of the Fossil Record (eds) P A Allison and D E G Briggs (New York: Plenum Press) Pp. 25-70.

Buczynski C and Chafetz H S 1991 Habit of bacterially induced precipitates of calcium carbonates influence of medium viscosity on mineralogy; J. Sed. Petrol. 61 $226-231$.

Castanier S, Metayer-Leverel G and Perthuisot J-P 1999 Ca-carbonate precipitation and limestone genesis - the microbiological point of view; Sed. Geol. 126 9-23.

Chafetz H S and Buczynski C 1992 Bacterially induced lithification of microbial mats; Palaios 7 277-293.

Chafetz H S and Folk R L 1984 Travertines; depositional morphology and bacterially constructed constituents; J. Sed. Petrol. 54 289-316.

Chaudhuri A K, Dasgupta S, Bandopadhyay G, Sarkar S, Bandopadhyay P C and Gopalan A K 1989 Stratigraphy of the Penganga Group around Adilabad, Andhra Pradesh; J. Geol. Soc. India 34 291-302.

Chaudhuri A K and Chanda S K 1991 The Proterozoic Basin of the Pranhita-Godavari Valley; an overview; In: Sedimentary Basins of India; tectonic context (eds) S K Tandon, C C Pant and S M Casshyap (Nainital: Gyanodaya Prakashani) Pp. 13-29.

Cölfen H and Antonietti M 1998 Crystal design of calcium carbonate microparticles using double-hydrophilic block copolymers; Langmuir 14 582-589.

Coleman M L 1985 Geochemistry of diagenetic non-silicate minerals; kinetic considerations; Phil. Trans. Royal Soc. London A315 39-56.

Curtis C D 1995 Post-depositional evolution of mudstones 1; early days and parental influences; J. Geol. Soc. London 152 577-586.

Curtis C D, Coleman M L and Love L G 1986 Pore water evolution during sediment burial from isotopic and mineral chemistry of calcite, dolomite and siderite concretions; Geochim. et Cosmochima Acta 50 2321-2334.

Dammer D, Chivas A R and Mcdougall I 1996 Isotopic dating of supergene manganese oxides from the Groote Eylandt Deposit, Northern Territory, Australia; Econ. Geol. 91 386-401.

Fan D and Yang P 1999 Introduction to and classification of manganese deposits of China; Ore Geol. Rev. 15 1-13.

Fan D, Ye J, Leiming Y and Zhang R 1999 Microbial processes in the formation of Sinian Gaoyan manganese carbonate ore Sichuan Province China; Ore Geol. Rev. 15 79-93.

Folk R L 1993 SEM imaging of bacteria and nannobacteria in carbonate sedimentary rocks; J. Sed. Petrol. 63 990-999.

Folk R L 1999 Nannobacteria and the precipitation of carbonate in unusual environments; Sed. Geol. 126 47-55.

Folk R L and Chafetz H S 2000 Bacterially induced microscale and nannoscale carbonate precipitates; In: Microbial Sediments (eds) R E Riding and S M Awarmik (Berlin: Springer-Verlag) Pp. 40-49.

Folk R L and Lynch F L 2001 Organic matter putative nannobacteria and the formation of ooids and hardgrounds; Sedimentology 48 215-229.

Frakes L A and Bolton B R 1992 Effects of ocean chemistry, sea level and climate on the formation of primary sedimentary manganese ore deposits; Econ. Geol. 87 1207-1217.

Gutzmer J and Beukes N J 1998 The manganese formation of the Neoproterozoic Penganga Group, India, revision of an enigma; Econ. Geol. 93 1091-1102.
Hein J R, Fan D, Ye J, Liu T and Yeh H-W 1999 Composition and origin of early Cambrian Tiantaishan phosphorite; Mn carbonate ores Shaanxi Province China; Ore Geol. Rev. 15 95-134.

Hein J R and Koski R A 1987 Bacterially-mediated diagenetic origin for chert-hosted manganese deposits in the Fransiscan Complex California Coast Ranges; Geology 15 $722-726$.

Huckriede H and Meischner D 1996 Origin and environment of manganese-rich sediments with black-shale basins; Geochim. et Cosmochima Acta 60 1399-1413.

Johnson K S, Coale K H, Berelson W M and Gordon R M 1996 On the formation of the manganese maximum in the oxygen minimum; Geochim. et Cosmochima Acta 60 1291-1299.

Krumbein W E and Swart P K 1983 The microbial carbon cycle; In: Microbial geochemistry (ed.) Krumbein W E (Oxford: Blackwell Scientific Publications) Pp. 5-63.

Little B J, Wagner P A and Lewandowski Z 1997 Spatial relationships between bacteria and mineral surfaces; In: Geomicrobiology; interactions between microbes and minerals (eds) J F Banfield and K H Nealson, Reviews in Mineralogy 35 123-159.

Lowenstam H A 1981 Minerals formed by organisms; Science 211 1126-1131.

Morad S and Al-Asam I S 1997 Conditions of rhodochrositenodule formation in Neogene-Pleistocene deep-sea sediments; evidence from O, C and Sr isotopes; Sed. Geol. $114295-304$.

Mukhopadhyay J 1997 Sedimentological Analysis and Reappraisal of Stratigraphy of the Proterozoic Penganga Succession around Adilabad Pranhita-Godavari Valley, Andhra Pradesh, Unpubl. PhD Thesis; Jadavpur University, p. 130.

Mukhopadhyay J, Chanda S K, Fukoaka M and Chaudhuri A K 1996 Deep-water dolomites from the Proterozoic Penganga Group in the Pranhita-Godavari Valley, Andhra Pradesh, India; J. Sed. Res. 66 223-230.

Mukhopadhyay J and Chaudhuri A K 2003 Stratigraphy of the Chanda Limestone, Proterozoic Penganga Group, Pranhita-Godavari Valley, Adilabad: Implications for depositional setting and paleogeography: J. Geol. Soc. India 62 356-368.

Mukhopadhyay J, Chaudhuri A K and Chanda S K 1997 Deep-water Manganese deposits in the mid-to-late Proterozoic Penganga Group of the Pranhita-Godavari Valley, South India; In: Manganese mineralization; geochemistry and mineralogy of terrestrial and marine deposits (eds) K Nicholson, J R Hein, B Bühn and S Dasgupta; Geol. Soc. London Spec. Publ. 119 $105-115$.

Mukhopadhyay J, Chaudhuri A K and Chanda S K 1999 Fabric development in Proterozoic bedded chert, Penganga Group, Adilabad, India; sedimentologic implications; J. Sed. Res. 69 738-746.

Nealson K H and Stahl D A 1997 Microorganisms and biogeochemical cycles; what can we learn from layered microbial communities? In: Geomicrobiology; interactions between microbes and minerals (eds) J F Banfield and $\mathrm{K}$ H Nealson; Reviews in Mineralogy $\mathbf{3 5}$ 5-33.

Neumann T, Heiser U, Leosson M and Kersten M 2002 Early diagenetic process during Mn-carbonate formation; evidence from the isotopic composition of authigenic Carhodocrosites of the Baltic Sea; Geochim. et Cosmochima Acta 66 867-879.

Okita P M 1992 Manganese carbonate minerailization in the Molango District, Mexico; Econ. Geol. 87 1345-1366. 
Okita P M, Maynard J B, Spiker E C and Force E R 1988 Isotopic evidence of organic matter oxidation by manganese reduction in the formation of stratiform manganese carbonate ore; Geochim. et Cosmochima Acta $\mathbf{5 2}$ 2679-2685.

Öztürk H and Hein J R 1997 Mineralogy and stable isotopes of black shale-hosted manganese ores southwestern Taurides Turkey; Econ. Geol. 92 733-744.

Polgãri M, Okita P M and Hein J R 1991 Stable isotope evidence for the origin of the Urkut manganese ore deposits Hungary; J. Sed. Petrol. 61 384-393.

Riding R 2000 Microbial carbonates; the geological record of calcified bacterial-algal mats and biofilms; Sedimentology 47 179-214.

Roy S 1997 Genetic diversity of manganese deposition in the terrestrial geological record; In: Manganese mineralization; geochemistry and mineralogy of terrestrial and marine deposits (eds) K Nicholson, J R Hein, B Bühn and S Dasgupta; Geol. Soc. London Spec. Publ. 119 5-27.

Sedlak M, Antonietti M and Cölfen H 1998 Synthesis of a new class of double-hydrophilic block copolymers with calcium binding capacity as builders and for biomimetic structure control of minerals; Macromol. Chemical Physics 199 247-254.

Seong-Joo L and Golubic S 1998 Multi-trichomous cyanobacterial microfossils from the Mesoproterozoic
Gaoyuzhuang Formation China; Paleoecological and taxonomic implications; Lethaia 31 169-184.

Skinner H C W 1993 A review of apatites iron and manganese minerals and their roles as indicators of biological activity in black shales; Precamb. Res. 61 209-229.

Westall F 1999 The nature of fossil bacteria; A guide to the search for extraterrestrial life; J. Geophys. Res. 104 $16,437-16,451$.

Westall F, Boni L and Guerzoni M E 1995 The experimental silicification of microorganisms; Paleontol. 38 $495-528$.

Westall F and Rincé Y 1994 Biofilms, microbial mats and microbe-particle interactions; electron microscope observations from diatomaceous sediments; Sedimentology $\mathbf{4 1}$ 147-162.

Westall F, Maarten J de Wit, Dann J van der, Gaast S, de Ronde C E J and Gerneke D 2001 Early Archean fossil bacteria and biofilm in hydrothermally-influenced sediments from the Barberton greenstone belt South Africa; Precamb. Res. 106 93-116.

Westall F, Steele A, Toporski J, Walsh M, Allen C, Guidry S, McKay D, Gibbson E and Chafetz H 2000 Polymeric substances and biofilms as biomarkers in terrestrial materials; Implications for extraterrestrial samples; J. Geophys. Res. 105 24,511-24,527. 